\title{
Isolasi dan Identifikasi Bakteri Pembentuk Biofilm dari Tambak Udang Balai Besar Pengembangan Budidaya Air Payau Jepara untuk Menghilangkan Amoniak
}

\author{
Ria Azizah TN*, Ita Riniatsih, Delianis Pringgenis, Chrisna Adhi Suryono dan \\ Suryono
}

\author{
Departemen IImu Kelautan, Fakultas Perikanan dan IImu Kelautan, Universitas Diponegoro \\ JI. Prof. Soedarto, SH. Kampus UNDIP Tembalang, Semarang 50275 \\ Email : riaazizahtn@yahoo.co.id
}

\begin{abstract}
Brackish water shrimp aquaculture activities often result in organic waste from excess of unconsumed foodstuff and biological waste from shrimp biological waste. The high organic contents increase the levels of ammonia, which is toxic to shrimp and many other aqua lives. One of the most widely used organic material biodegradation system as biofilters, biofilm has not yet seen many uses in shrimp aquafarm waste management. This study aims to isolate and screen biofilm-forming primary bacteria with abilities to degrade ammoniacal nitrogen compounds. The processes involved in this study are location survey, wooden and fiber panel installation, planting of panel in the ponds, isolation of bacteria by dispersion method, purification of primary bacteria by scratch method. Ammoniacal nitrogen degradation test was performed by Microwell Plate Chromatogram Assay and UV-Vis Spectrophotometry. The analysis of the bacteria isolates found 66 primary bacteria with biofilm formation abilities. Based on qualitative analysis, 20 isolates displayed potential in degrading ammoniacal nitrogen compound and 7 isolates showed low (<10\%) capacity in degrading ammoniacal nitrogen.
\end{abstract}

Key words: biofilm-forming primary bacteria, ammoniacal nitrogen, degradation

\begin{abstract}
Abstrak
Kegiatan budidaya udang di tambak akan menghasilkan limbah organik yang berasal dari sisa pakan yang tidak termakan maupun kotoran udang. Kandungan bahan organik yang tinggi akan meningkatkan kandungan amonia yang bersifat toksik bagi udang dan biota air lainnya. Salah satu sistem biodegradasi bahan organik yang telah banyak digunakan sebagai biofilter namun belum dimanfaatkan dalam pengolahan limbah organik tambak udang adalah biofilm. Tujuan dari penelitian ini adalah mengisolasi dan skrining bakteri primer pembentuk biofilm yang mampu mendegradasi senyawa amonia nitrogen. Untuk mencapai tujuan tersebut, maka beberapa tahap penelitian yang telah dilakukan adalah survei lokasi tambak udang, pemasangan panel bahan kayu dan fiber, penanaman panel dalam badan air tambak, mengisolasi bakteri dengan metode sebaran, purifikasi bakteri primer pembentuk biofilm dengan metode goresan. Uji oksidasi amonium nitrogen dilakukan secara kualitatif dan kuantitatif dengan metode Micro well plate chromatogram assay dan UV-Vis Spektrofotometer. Hasil penelitian menunjukkan bahwa hasil isolasi diperoleh sebanyak 66 isolat bakteri primer pembentuk biofilm. Berdasarkan uji kualitatif diperoleh 20 isolat yang memiliki potensi mendegradasi senyawa amoniurn nitrogen. Namun hasil uji kuantitatif bakteri seleksi pendegradasi amonium nitrogen menunjukkan 7 isolat yang memiliki kemampuan rendah (<10\%) mendegradasi amonium nitrogen.
\end{abstract}

Kata kunci: bakteri primer pembentuk biofilm, amonia nitrogen, degradasi 


\section{PENDAHULUAN}

Kegiatan budidaya udang di tambak menghasilkan limbah organik baik yang berasal dari sisa pakan yang tidak termakan maupun kotoran udang serta plankton yang mati (Suwoyo et al., 2014). Sisa pakan dan bahan organik berbentuk limbah tersebut dalam industri tambak udang dapat mencapai $60 \%$ dari total porsi pengeluaran usaha budidaya udang dan hilang begitu saja untuk dibuang ke perairan di sekitarnya. Selain kehilangan ongkos yang tinggi, limbah organik dapat mencemari lingkungan perairan tambak maupun lingkungan pantai sekitamya. Kandungan bahan organik yang tinggi akan meningkatkan kandungan ammonia yang bersifat toksik bagi udang dan biota air lainnya. Batas kandungan ammonia tertinggi dalam perairan tambak udang adalah $0,1 \mathrm{mg} / \mathrm{l}$ sedangkan batas tertinggi kandungan total bahan organik adalah 60 mg/l (Hendrawati et al., 2014) Untuk mempercepat penurunan kandungan bahan organik dan ammonia yang beracun tersebut saat ini para petani tambak telah menggunakan bakteri pengurai. Akan tetapi, hasilnya tidak selalu baik karena bakteri pengurai (probiotik) membutuhkan kondisi dan nutrisi tertentu untuk mempertahankan keberadaannya.

Pemanfaatan limbah organik untuk budidaya sel protein tunggal, seperti Spirulina telah banyak dilakukan akhir-akhir ini. Beberapa peneliti seperti Sumantri et al. (2010) telah memanfaatkan mikroalgae untuk pengolahan air limbah cair yang mengandung ammonia tinggi. Azizah et al. (1998) telah membudidayakan Spirulina dengan menggunakan limbah cair. Hal ini dilakukan karena spirulina dapat menyerap ammonia yang terionisasi atau ammonium (NH4) sebagai nutrisi untuk meningkatkan pertumbuhannya (Danesi et al., 2002). Namun muncul banyak kekhawatiran pada tingkat keamanan penyediaan pangan dengan memanfaatkan limbah, yaitu kontaminasi zat beracun dan bakteri patogen. Untuk itu perlu dilakukan upaya upaya dalam menurunkan kandungan bahan organik yang terkandung dalam limbah organik dan berupaya memanfaatkan limbah untuk kebutuhan manusia dengan aman.
Komunitas bakteri pada biofilm ini dipercaya akan merubah bahan-bahan organik melalui proses amonifikasi dan nitrifikasi. Aplikasi biofilm ini akan menurunkan kadar ammonia dalam limbah organik tambak udang dan akan meningkatkan kadar nitrat didalamnya. Dalam penerapannya perlu dilakukan ujicoba penumbuhan biofilm dengan menggunakan media berpermukaan yang luas sehingga dapat menampung pertumbuhan biofilm lebih padat dan dapat meningkatkan biokonversi limbah organik tambak udang. Ketebalan biofilm menunjukkan padatnya komunitas mikroorganisme penyusunnya (Stanley et al., 2005). Untuk itu ujicoba dengan menggunakan substrat yang memiliki permukaan luas seperti fiber bergelombang. Tujuan penelitian ini adalah melihat aktifitas bakteri terhadap adanya biofilm pada tambak udang.

\section{MATERI DAN METODE}

Materi yang digunakan dalam penelitian ini adalah bakteri pembentuk biofilm yang di substrat kayu dan fiber yang ditanam pada BBPBAP (Balai Besar Pengembangan Budidaya Air Payau) Jepara. Biofilm ditumbuhkan dengan cara merendam kayu dan fiber masing-masing sebanyak 2 set di area pertambakan BBPBAP (Balai Besar Pengembangan Budidaya Air Payau) Jepara.

Penelitian ini digunakan Media Zobell 2216E, pembuatan dengan cara ditimbang 15,0 gr Bacto-agar, 5,0 gr Bactopeptone, 1,0 gr yeast ekstrak dan 19,5 mg Feri fosfat, dimasukkan ke dalam labu Erlenmeyer ditambahkan air laut steril hingga mencapai volume 1 liter. Pada Labu erlenmeyer tersebut diletakkan magnetic stirrer, dipanaskan di atas hot plate hingga mendidih dan homogen. $\mathrm{pH}$ ditentukan hingga 7,5 - 7,6 dan kemudian media tersebut disterilisasikan dengan menggunakan autoklaf pada suhu $121^{\circ} \mathrm{C}$ dengan tekanan $1 \mathrm{~atm}$ selama 20 menit. (Nofiani dan Sapar, 2009)

Metode yang akan digunakan untuk mengisolasi bakteri adalah metode Pour plate (Agar tuang). Kayu dan fiber 
berukuran $1 \mathrm{~m} \times 50 \mathrm{~m}$ yang sudah diambil dari lokasi tambak ditempatkan pada cawan petri steril yang berisi air laut steril. Sampel digojok dan diambil $10 \mathrm{ml}$ dari masing-masing sampel, dimasukkan ke dalam labu erlenrneyer yang berisi $90 \mathrm{ml}$ air laut steril, dikocok hingga homogen dan diperoleh pengenceran $10^{-1}$. Selanjutnya dari pengenceran $10^{-1}$ diambil $1 \mathrm{ml}$ contoh air dengan menggunakan pipet steril, yang dimasukkan ke dalam $9 \mathrm{ml}$ aquadest steril dan diperoleh pengenceran 10-2. Pengenceran hingga diperoleh pengenceran $10^{-3}, 10^{-4}$ dan $10^{-5}$. Masingmasing diambil $1 \mathrm{ml}$ contoh air dengan menggunakan pipet steril dan dimasukkan ke dalam masing-masing cawan petri steril. Selanjutnya di tambahkan ke dalamnya 15 $\mathrm{ml}$ media Zobell dengan suhu sekitar $45^{\circ} \mathrm{C}$ yang telah dicairkan sebelumnya dengan menggunakan pemanas. Selanjutnya cawan petri tersebut dibungkus dengan kertas pembungkus dan diinkubasikan selama $2 \times 24$ jam. (Purkan. 2016)

Uji oksidasi senyawa amonium nitrogen dilakukan dengan menggunakan metode Micro-well-plate chromatogram assay (Zhao et al., 2013). Dalam media cair Zobel 2216E ditambahkan senyawa (NH4)2SO4, 472 g; $\mathrm{KH} 2 \mathrm{PO} 4,7.25$ g; Na2HPO4, 11.32 g; $\mathrm{CH} 3 \mathrm{COONa}, 80 \mathrm{~g}$; MgSO4, 200 g; $\mathrm{CaC} 12,20 \mathrm{~g}$; $\mathrm{NaHCO} 3,85 \mathrm{~g}$ per liter akuades. Lalu tambahkan elemen A dan B (dibuat pH akhir sekitar 8.0) dan disterilkan dengan autoklaf. Kemudian masukkan dalam tiap sumur mikroplate media sebanyak $200 \mu \mathrm{l}$ dan $20 \mu \mathrm{l}$ kultur bakteri uji dan diinkubasikan dalam suhu ruang selama 24 jam. Perubahan warna media cair diamati untuk mengetahui perubahan wama yang terjadi.

Ditimbang 2,5 gram Bacto-peptone, 0,5 gram yeast ekstrak dan 19,5 mg Feri fosfat, kemudian dimasukkan ke dalam labu Erlenmeyer yang kemudian dituangi air laut steril hingga mencapai volume 1 liter. Nilai pH ditentukan hingga 7,5 - 7,6 dan kemudian dipersiapkan beberapa gelas erlenmeyer Pyrex $25 \mathrm{~m}$ untuk dituangi volume masing-masing sebesar $10 \mathrm{ml}$ dari media cair tersebut, lalu disterilisasikan dengan menggunakan autoklaf pada suhu $121^{\circ} \mathrm{C}$ dengah tekanan $1 \mathrm{~atm}$ selama 20 menit. Setelah dingin, ke dalam labu erlenmeyer tersebut ditambahkan Amonia Nitrogen ditentukan konsentrasi $100 \mathrm{ml} / \mathrm{l}$. Selanjutnya tiap isolat bakteri biofilm diinokulasi ke dalam tabung reaksi tersebut dan di inkubasikan pada suhu kamar dengan digoyang (shaker) selama 48 jam. Oksidasi Amonia Nitrogen diukur menggunakan UV spektrofotometer dengan $\lambda=550 \mathrm{~nm}$ dengan interval 24 jam. Pengamatan pertumbuhan dilakukan dengan Vis spektrofotometri $\lambda=600$ dan menimbang berat biomass sel bakteri setelah disentrifugasi.

Identifikasi bakteri pada beberapa isolat murni yang memiliki daya degradasi dilakukan menurut Bergey's Manual of Systematic Bacteriology (Sneath et al., 1986) didasarkan pada uji pewarnaan gram, uji motilitas dan uji biokirnia.

\section{HASIL DAN PEMBAHASAN}

Hasil isolasi dan purifikasi bakteri primer pembentuk biofilm dari subtrat kayu dan fiber yang ditanam pada tambak. Hasil isolasi bakteri dari subtrat kayu dan fiber diperoleh 66 isolat bakteri primer pembentuk biofilm (Tabel 1 dan Tabel 2). Koloni bakteri primer pembentuk biofilm di lingkungan tambak memiliki keragaman yang sangat tinggi. Dilihat dari wama koloni, terlihat bahwa koloni bakteri yang behasil diisolasi berwama putih, kuning, merah muda, ungu, dan ungu tua. Apabila dilihat dari bentuk morfologinya bakteri koloni berbentuk bulat, bulat bergelombang dan bulat bergerigi. Sidharta (2000) melaporkan bahwa berdasarkan morfologi bahwa ada sekitar $80 \%$ bakteri laut yang diketahui berbentuk batang dan bersifat gram negative. Pleomorfisme umum terjadi pada bakteri laut dibandingkan bakteri sungai, danau, dan tanah. Lebih lanjut Sidharta (2000) melaporkan bahwa sekitar seperlima bakteri batang dari laut berbentuk kumparan helicoid, sehingga sering diklasifikasikan sebagai Vibrio atau Spirulina. Bakteri laut bergerak secara aktif, antara $75-85 \%$ sediaan murni yang diamati memiliki flagel. Diperkirakan kemampuan bergerak ini sebagai hasil adaptasi kehidupan perairan. Jenis-jenis Pseudomonas, Vibrio, Flavobacterium, Achromobacter dan Bacterium 
merupakan jenis terbanyak yang dijumpai di laut.

Bakteri akan membentuk lapisan film, yang pada keadaan tertentu menjadi pelapis luar cat antifouling, sehingga tidak berpengaruh terhadap organisme fouling. Secara perlahan bakteri akan merombak senyawa penyusun pelapis atau cat. Di sisi lain, bakteri juga mencegah organisme lain yang lebih besar untuk tinggal bersama melalui antibiotik yang dihasilkannya. Total bakteri primer pembentuk biofilm yang dihasilkan dari subtrat fiber sebanyak 29 isolat, sedangkan total bakteri primer pembentuk biofilm yang dihasilkan dari subtrat kayu sebanyak 37 isolat. Banyak penelitian yang melaporkan keberhasilan mengisolasi bakteri primer pembentuk biofilm dari permukaan benda hidup maupun benda mati. Merina et al. (2010) melaporkan bahwa bakteri primer pembentuk biofilm pada permukaan daun sea grass Halodule pinifolia didominasi oleh jenis bakteri Bacillus pumilus, disamping jenis bakteri lainnya seperti genus Pseudomonas sp., Staphylococcus sp. dan E. Coli. Sedangkan Kolari et al. (2001) melaporkan bahwa bakteri primer pembentuk biofilm pada permukaan mesin keflas juga didominasi oleh species Bacillus sp. Gao et al. (2012) melaporkan bahwa jenis bakteri pembentuk biofilm pada filter aerasi tambak udang dari bamboo didominasi oleh jenis Bacteroidetes, Alphaproteobacteria Denitromonas.

Hasil uji bakteri primer pembentuk biofilm pendegradasi amonium nitrogen secara kualitatif. Dari hasil uji tersebut

Tabel 1. Isolat Bakteri Primer pembentuk biofilm dari substrat fiber

\begin{tabular}{|c|c|c|c|c|}
\hline No & Kode Isolat & Bentuk & Warna & Tekstur \\
\hline 1. & FAl.1 & Bulat Gelombang & Orange, Pinggir bening & Cembung \\
\hline 2. & FA 1.2 & Bulat & Orange pucat, pinggir putih & Cembung \\
\hline 3. & FA 1.3 & Bulat Gelombang & Putih gading & Cembung \\
\hline 4. & FA 1.4 & Bulat & Putih gading, pinggir bening & Cembung \\
\hline 5. & FA 1.5 & Bulat & Putih kebiruan, putih & Cembung \\
\hline 6. & FA 1.6 & Bulat Gelombang & Bening & Datar \\
\hline 7. & FA 1.7 & Bulat & Kuning pucat, berinti & Cembung \\
\hline 8. & FA 1.8 & Bulat & Putih gading, pinggir bening & Cembung \\
\hline 9. & FA 1.9 & Bulat Gelombang & Kuning pucat & Cembung \\
\hline 10. & FA 1.10 & Bulat Gelombang & Kuning pucat & Cembung \\
\hline 11. & FA 1.11 & Bulat & Putih susu & Cembung \\
\hline 12. & FA 1.12 & Bulat & Orange pucat & Cembung \\
\hline 13. & FA 1.13 & Bulat Gelombang & Bening berinti & Cembung \\
\hline 14. & FA 1.14 & Bulat & Putih susu, pinggir putih & Cembung \\
\hline 15. & FB 2.1 & Bulat & Kuning, pinggir bening & Cembung \\
\hline 16. & FB 2.2 & Bulat & Putih gading & Cembung \\
\hline 17. & FB 2.3 & Bulat & Kuning, pingair bening & Cembung \\
\hline 18. & FB 2.4 & Bulat Gelombang & Kuning, pinggir bening & Cembung \\
\hline 19. & FB 2.5 & Bulat & Putih gading bening & Cembung \\
\hline 20. & FB 2.6 & Bulat & Putih merah jambu & Cembung \\
\hline 21. & FB 2.7 & Bulat & Putih pinggir bening, berinti & Cembung \\
\hline 22. & FB 2.8 & Bulat & Putih gading berinti & Cembung \\
\hline 23. & FB 2.9 & Bulat & Putih gading, pinggir bening & Cembung \\
\hline 24. & FB 2.10 & Bulat & Putih susu berinti & Cembung \\
\hline 25. & FB 2.11 & Bulat & Kuning, pinggir bening & Membukit \\
\hline 26. & FB 2.12 & Bulat & Orange tua, tepi bening & Cembung \\
\hline 27. & FB 2.13 & Bulat & Orange pucat, tepi bening & Cembung \\
\hline 28. & FB 2.14 & Bulat & Kuning pucat bening & Cembung \\
\hline 29. & FB 2.15 & Bulat & Orange tua & Cembung \\
\hline
\end{tabular}


Tabel 2. Isolat Bakteri Primer pembentuk biofilm dari substrat kayu

\begin{tabular}{|c|c|c|c|c|}
\hline No & Kode Isolat & Bentuk & Warna & Tekstur \\
\hline 1. & KA 1.1 & Bulat & Putih susu, bening & Cembung \\
\hline 2. & KA 1.2 & Bulat & Kuning & Cembung \\
\hline 3. & KA 1.3 & Bulat & Kuning gading & Cembung \\
\hline 4. & KA 1.4 & Bulat & Bening & Cembung \\
\hline 5. & KA 1.5 & Bulat & Ungu tua & Cembung \\
\hline 6. & KA 1.6 & Bulat & Putih gading & Cembung \\
\hline 7. & KA 1.7 & Bulat & Putih susu & Cembung \\
\hline 8. & KA 1.8 & Bulat & Putih susu & Cembung \\
\hline 9. & KA 1.9 & Bulat & Putih susu & Cembung \\
\hline 10. & KA 2.1 & Bulat & Putih susu & Cembung \\
\hline 11. & KA 2.2 & Bulat kecil & Putih gading & Cembung \\
\hline 12. & KA 2.3 & Bulat & Putih, tepi bening & Cembung \\
\hline 13. & KA 2.4 & Bulat & Putih berlapis bening & Cembung \\
\hline 14. & KA 2.5 & Bulat & Orange & Cembung \\
\hline 15. & KA 2.6 & Bulat & Merah tua & Cembung \\
\hline 16. & KA 2.7 & Bulat & Merah & Cembung \\
\hline 17. & KA 2.8 & Bulat & Bening & Cembung \\
\hline 18. & KB 1.1 & Bulat & Merah tua & Cembung \\
\hline 19. & KB 1.2 & Bulat & Kuning gading & Cembung \\
\hline 20. & KB 1.3 & Bulat & Bening, putih pucat & Cembung \\
\hline 21. & KB 1.4 & Bulat & Kuning, putih & Cembung \\
\hline 22. & KB 1.5 & Bulat & Bening & Membukit \\
\hline 23. & KB 1.6 & Gerigi, berkerut & Putih susu, kuning & Cembung \\
\hline 24. & KB 1.7 & Bulat & Kuning, tepi putih & Kawah \\
\hline 25. & KB 1.8 & Bulat & Putih gading & Cembung \\
\hline 26. & KB 1.9 & Bulat & Bening kekuningan & Cembung \\
\hline 27. & KB 1.10 & Bulat & Bening mengkilap & Cembung \\
\hline 28. & KB 1.11 & Bulat kecil & Bening & Cembung \\
\hline 29. & KB 1.12 & Bulat & Bening keputihan & Cembung \\
\hline 30. & KB 1.13 & Bulat & Putih susu & Cembung \\
\hline 31. & KB 1.14 & Bergelombang & Merah jambu pucat & Cembung \\
\hline 32. & KB 2.1 & Bulat & Putih & Cembung \\
\hline 33. & KB 2.2 & Bulat & Putih gading & Cembung \\
\hline 34. & KB 2.3 & Bulat & Kuning gading & Cembung \\
\hline 35. & KB 2.4 & Bulat & Putih gading & Cembung \\
\hline 36. & KB 2.5 & Bulat & Putih gading & Cembung \\
\hline 37. & KB 2.6 & Bulat & Putih gading & Cembung \\
\hline
\end{tabular}

diperoleh 20 isolat yang memiliki potensi mengoksidasi senyawa Amonium Nitrogen. Kemampuan mengoksidasi isolat ditunjukkan dengan adanya perubahan wama pada medium. Selanjutnya dari ke20 bakteri seleksi tersebut akan dilakukan re-skrining dengan melakukan uji kuantitatif. Dengan menggunakan indikator media, Zhao et al. (2013) menemukan 7 isolat bakteri yang mampu mengoksidasi amonia nitrogen. Hasil uji bakteri primer pembentuk biofilm pengoksidasi amonium nitrogen secara kuantitatif alam medium minimal yang diperkaya dengan 100 ppm nitrogen ammonia (Tabel 3). Dari tabel tersebut dapat dilihat bakteri isolat biofilm memiliki kemampuan kecil di dalam mengoksidasi senyawa tersebut. Hasil penelitian uji oksidasi bakteri pembentuk biofilm menunjukkan bahwa isolat-isolat bakteri tersebut tidak memiliki atau memiliki kemampuan mengoksidasi yang sangat rendah jika dibandingkan dengan hasilhasil penelitian terdahulu. Bakteri primer pembentuk biofilm hanya mampu 
Tabel 3. Hasil Uji kuantitatif

\begin{tabular}{|c|c|c|c|}
\hline $\mathrm{Nc}$ & Isolat & $\mathrm{NH} 4^{+}-\mathrm{N}$ & Oksidasi $\mathrm{NH}_{4}^{+}-\mathrm{N}(\%)$ \\
\hline 1. & FA 1.2 & 102 & $-1,98$ \\
\hline 2. & FA 1.5 & 100 & 0,00 \\
\hline 3. & FA 1.6 & 99 & 0,99 \\
\hline 4. & FA 1.10 & 97 & 2,97 \\
\hline 5. & FA 1.14 & 101 & $-0,99$ \\
\hline 6. & FB 2.2 & 101 & $-0,99$ \\
\hline 7. & FB 2.13 & 100 & 0,00 \\
\hline 8. & FB 2.15 & 102 & $-1,98$ \\
\hline 9. & KA 1.3 & 97 & 2,97 \\
\hline 10. & KA 1.7 & 96 & 3,96 \\
\hline 11. & KA 1.9 & 100 & 0,00 \\
\hline 12. & KB 1.1 & 100 & 0,00 \\
\hline 13. & KB 1.3 & 100 & 0,00 \\
\hline 14. & KB 1.10 & 94 & 5,94 \\
\hline 15. & KB 1.11 & 100 & 0,00 \\
\hline 16. & KB 1.12 & 93 & 6,93 \\
\hline 17. & KB 1.13 & 99 & 0,99 \\
\hline 18. & KB 2.2 & 101 & $-0,99$ \\
\hline 19. & KB 2.4 & 102 & $-1,98$ \\
\hline 20. & KB 2.5 & 100 & 0,00 \\
\hline
\end{tabular}

mengoksidasi senyawa Amonium Nitrogen kurang dari 10 persen. Hasil penelitian terdahulu yang dilakukan oleh Zhao et al. (2013) dari bakteri yang diisolasi dari limbah buangan rumah sakit menunjukkan kemampuan mengoksidasi senyawa $\mathrm{NH} 4+-$ $\mathrm{N}$ sebesar 46-84 \%. Oksidasi senyawa amonia menjadi nitrit merupakan langkah awal didalam proses penurunan nitrogen secara biologi. Sehingga bakteri biofilm yang dihasilkan dalam studi ini tidak dapat digunakan sebagai pengolah nitrogen organik dalam perairan tambak. Dalam beberapa tahun terakhir ini, penggunaan proses BNR (Biological Nutrient Removal) secara baru dengan teknik SHARON (single high ammonia removal over nitrite) dan ANAMMOX (anaerobic ammonium oxidation) telah diteliti secara luas dan mendalam (Schmidt et al, 2003; Ahn, 2006). Bakteri Nitrosomonas eutropha mempunyai kemampuan melakukan nitrifikasi dan denitrifikasi bersamaan (Zhou et al., 2013).

\section{KESIMPULAN}

Pada penelitian ini dapat disimpulkan bahwa bakteri primer pembentuk biofilm yang diisolasi dari subtrat kayu dan fiber diperairan tambak
Jepara tidak dapat dijadikan sebagai kandidat bioremediator senyawa amonia nitrogen di tambak karena hanya memiliki kemampuan kecil di dalam mengoksidasi senyawa ammonia nitrogen.

\section{DAFTAR PUSTAKA}

Ahn, Y.H., 2006. Sustainable nitrogen elimination biotechnologies: A Review. Process. Biochem, 41: 1709-1721

Azizah, R., Pujiastuti, J., Widianingsih, Supriyantini, E. \& Hermawan, I. 1998. Pemanfaatan Air Limbah Pertambakan sebagai Media Kultur Spirulina sp. Laporan Penelitian Fakultas Perikanan dan IImu Kelautan. Universitas Diponegoro, 24 halaman.

Danesi, E,D,G., C de O Rangel-Yagui, de Carvalho, J.C.M. \& Sato. S. 2002. An investigation of effect of replacing nitrate by urea in the growth and production of chlorophyll by Spirulina platensis. Biomass and Bioenergy. 23 (4):261-269

Gao, X.Y., Xu, Y., Liu, Y., Liu, Y. \& Liu, Z.P. 2012. Bacterial diversity, community structure and function associated with biofilm development in a biological aerated filter in a recirculating marine 
aquaculture system. Marine Biodiversity. 42(1): 1-11

Hendrawati, H., Prihadi, T.H. \& Rohmah, N.N., 2008. Analisis kadar phosfat dan $\mathrm{N}$-nitrogen (amonia, nitrat, nitrit) pada tambak air payau akibat rembesan lumpur lapindo di Sidoarjo, Jawa Timur. Jurnal Kimia VALENSI, 1 (3).

Kolari, M., Nuutinen, J. \& Salkinoja-Salonen, M.S. 2001. Mechanisms of biofilm formation in paper machine by Bacillus species: the role of Deinococcus geothermalis. J. Industrial Microbiology \& Biotechnology, 27:343-351.

Sneath, P.H.A., Mair, N.S., Sharpe, M.E. \& Holt, J.G. 1986. Bergey's manual of systematic bacteriology, vol. 2. Williams \& Wilkins, Baltimore, Md

Merina, M., Lipton, A.P. \& Wesley, S.G. 2011. Isolation, characterization and growth of biofilm forming bacteria Bacillus purnilus from the seagrass, Halodule pinifolia of Kanyakumari coast. Indian J . Mar. Sci. 40(3): 443-448

Nofiani, R. \& Sapar, A., 2009. Characteristics of Antimicrobial Activity of Eucheuma cottonii Doty-Associated Bacteria Extracts. Jurnal Pengolahan Hasil Perikanan Indonesia, 12(2).

Purkan, P., Nurmalyya, S. \& Hadi, S., 2016. Resistance Level of Pseudomonas stutzeri Against Mercury And Its Ability In Production Of Mercury Reductase Enzyme. Molekul. 11 (2):230-238
Schmidt, I., Sliekers, O., Schmid, M., Bock, E., Fuerst, J., Kuenen, J.G., Jetten, M.S.M. \& Strous, M. 2003. New concepts of microbial treatment processes for the nitrogen removal in wastewater, FEMS Microbiol. Rev. 27:481-492.

Sidharta, B.R. 2000. Sifat-sifat Bakteri Laut; Pengantar Mikrobiologi Kelautan. Yogyakarta; Universitas Atmajaya: 1-13

Stanley, C., Lau, K., Thiyagarajan, V., Cheung, S.C.K \& Qian, P.Y. 2005. Roles of bacterial community composition in biofilms as a mediator for larval settlement of three marine invertebrates. Aquat. Microb. Ecol. 38:41-51

Sumantri, I., Sumarno \& Afiati, N. 2010. Pengolahan limbah cair pupuk kadar amoniak tinggi dengan proses gabungan mikroalgae dan nitrifikasidenitrifikasi autotrofik. Proseding Seminar Nasional Sains dan Teknologi. Universitas Wahid Hasyim. Semarang: B35-40

uwoyo, H.S., Undu, M.C. and Makmur, M., 2014, December. Laju Sedimentasi Dan Karakterisasi Sedimen Tambak Super Intensif Udang Vaname (Litopenaeus vannamei). In Prosiding Forum Inovasi Teknologi Akuakultur (pp. 327-339).

Zhao,C., Song, W.. Wei, J. \& Li, B. 2013. Rapid Screening of Ammonia Oxidizing Bacteria in the Sewage. Int. J. Biosci. Biochem. Bioinfor. 3(2) 